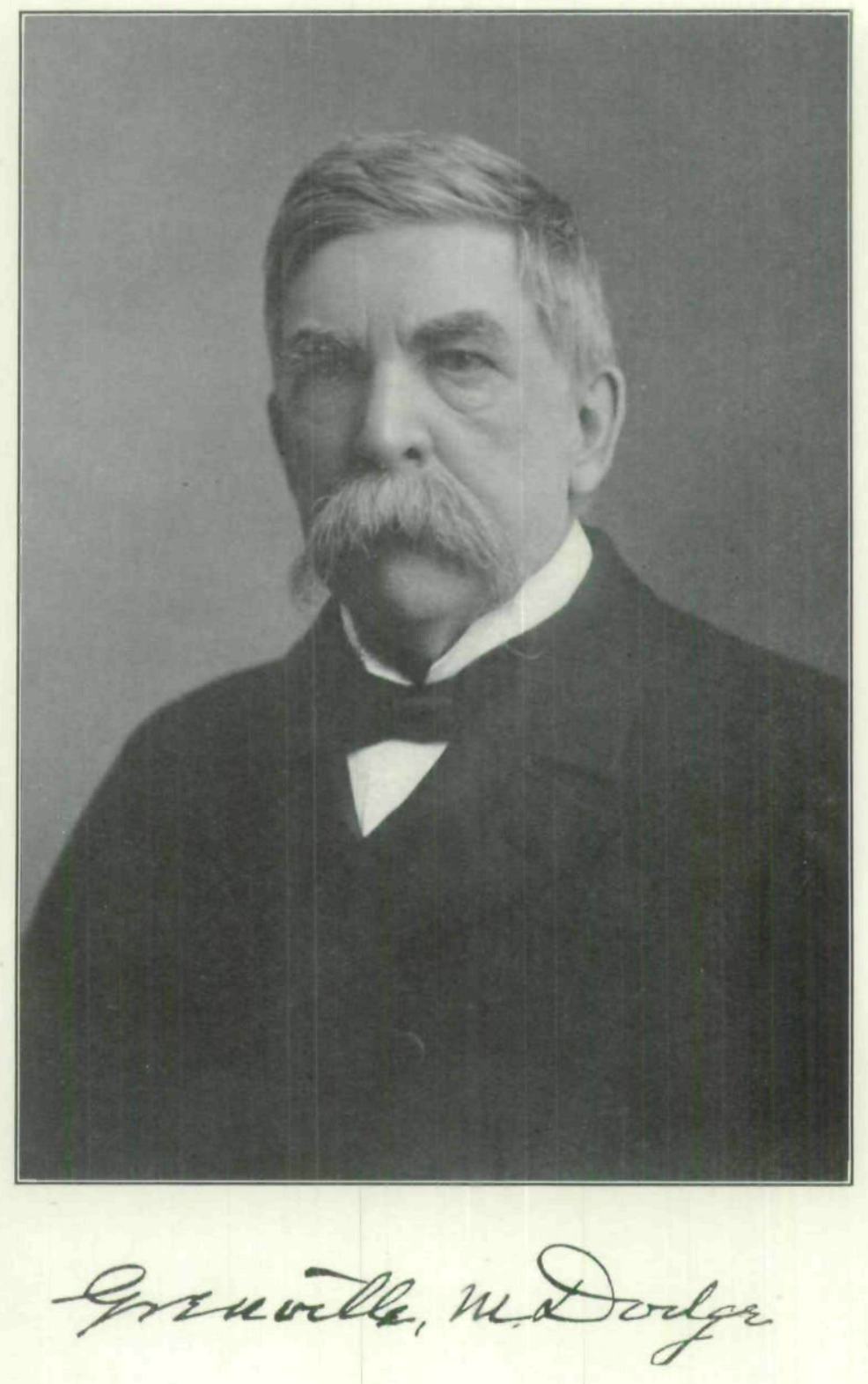




\section{GEN. G. M. DODGE'S HISTORICAL ADDRESS.}

At the Camp Fire of the Crocker Brigade, at Keokuk, Iowa, on the 27th day of September, 1900, Major General G. M. Dodge delivered the following address, in which he reviewed the military operations of that command during the civil war. The paper includes several interesting letters by Gen. Crocker, as well as Gen. Dodge's estimate of the value of the military services of that illustrious soldier and of Generals Samuel R. Curtiss, William W. Belknap and James A. Williamson. It is a historical document of great value.

THE COUNCIL BLUFFS GUARDS.

Comrades of the Crocker Brigade: In 1853 I made my first survey across the State of Iowa for a railroad terminating at Council Bluffs. Examinations which I had made on the western plains caused me to firmly believe that if a railway to the Pacific was ever built it would occupy the Great Platte Valley, and have its eastern terminus in the vicinity of Council Bluffs. I, therefore, chose that place as my future home. My profession as a civil engineer kept me so busy that it was 1854 before I had an opportunity to settle down in my new home. My explorations satisfied me that the frontier was in an unprotected condition, and in $1856 \mathrm{I}$ organized, armed and equipped (with the aid of the Governor) a military company, known at that time as the "Council Bluffs Guards," and now as the "Dodge Light Guards."

At that time there was no law in the State of Iowa providing for such organizations, or for in any manner supporting them, so it was only the love for the military that induced anyone to take part in such an organization, and I assure you that at first it was uphill work. My duties kept me on my explorations either east or west, so that I was able to give but little attention to the company. I drilled it thoroughly, however, and had in Lieutenants J. H. Craig, W. H. Kinsman and George E. Ford, young men, spirited fellows, who, in my absence, kept up the organization and felt pride in it.

MEETING WITH M. M. OROCKER, AND ATTEMPT TO PASS A MILITIA LAW.

Not long after I had organized this company I received a letter from M. M. Crocker, which was very characteristic of 
the man. He said he wanted to become acquainted with a man who had the nerve and the presumption to raise a military company in Iowa, and maintain it, as I had the Guards, and asked me to let him know whenever I happened to be in Des Moines, so that he might call to see me. I am not certain, but think that Crocker had tried to raise a company in Des Moines. Soon afterwards we met and became acquainted with each other, and from that day until the time of his death, we were close, fast friends.

Crocker had a great love for the military, and was very anxious that the State should pass a law that would arm, equip and uniform an active militia, with independent companies, and prevailed upon me to take hold of the matter with him. We drafted a good bill, patterned after those of the eastern states, but adapted to the limited population and means of Iowa. I went to Des Mcines and had it introduced in the legislature, and, as he was on the ground, Crocker took charge of it. Some time afterwards he wrote me that if I would come on to Des Moines and go before the legislature, he thought the bill could be passed. I believe at that time there was an independent company at Dubuque, and, perhaps, at some other point on the Mississippi river.

I went to Des Moines. The bill was taken up at an evening session, and was kicked and cuffed all over that legislative hall, amended, disfigured, and made so disreputable that it was impossible to recognize it. They really reflected on us for being such idiots as in those days to think of organizing a military force in Iowa, and were of the opinion that persons guilty of spending their time in such work were proper subjects for the insane asylum. We were both thunderstruck at our treatment. I was humiliated and chagrined; Crocker was mad all over, and if any of you have ever seen him mad, you can judge what his language was. We went down to the Kirkwood House, where many of the members of the legislature lived, and when they began to come in Crocker went at them, and I never heard such a 
denunciation and word-mauling as he gave them, and, to my astonishment, he made them see what fools they had made of themselves. They proposed to take the matter up again, but I had measured the militarism of that legislature, and, declining to have anything more to do with it, returned to the Bluffs and kept up my own company, which increased in numbers, but was so poor that it was difficult to keep it in a presentable condition as to arms and dress. But the military spirit was growing in the Bluffs. The Indians were threatening and creating disturbances, and Captain Samuel C. Clinton raised an artillery company, which had two six-pound guns. The two companies drifted along until 1861. All this time Crocker was praising and supporting us, writing items for the press, and endeavoring to arouse a military spirit throughout the State.

\section{COUNCIL BLUFFS GUARDS OFFERS ITS SERVICES TO THE} GOVERNOR.

When we were threatened with civil war in $1861 \mathrm{I}$ felt it would be my duty to take part in it, and so informed the company, stating, that in my opinion, we should declare ourselves. At that time Council Bluffs was settled principally by Mormons-and Southerners, and I was greatly astonished to find that every member of the company voted to enlist. I was authorized to offer the services of the company to the Governor, and it is my recollection that Governor Kirkwood stated that it was the first company to offer its services to Iowa in the civil war. The Governor, however, felt constrained to decline the offer of the company's services, giving as his reason in a letter to me that it was the only organized company in western Iowa, and its services and influence were needed there, as there were all kinds of rumors of what the Missourians and Indians would do. I was not so fortunate as Crocker, for upon the declaration of war he immediately raised a company and had it accepted in the Second Iowa Infantry.

VoL. IV, -37 
APPOINTMENT ON GOVERNOR'S STAFF-SENT TO WASHINGTON FOR ARMS.

I wrote Crocker that I was going to Washington to enter the service. The Governor learned of my intention (no doubt through Crocker), and I was immediately placed on his staff, and sent to Washington to obtain arms and equipments for the State. Our Senators and Members of Congress had failed to provide any. I immediately proceeded to St. Louis, where I saw General W. S. Harney, whom I had been acquainted with in my explorations on the plains. He had no arms, but told me that at the Pittsburgh, or some other eastern arsenal, there were about ten thousand stand that appeared to have been overlooked. I proceeded to Washington, where I met Fitz Henry Warren of our State, then the correspondent in Washington for The New York Tribune, and a power with the administration. He took me to Simon Cameron, the Secretary of War, who informed me that there were no arms, and he could not furnish the State with a single gun. I asked him if I could find arms belonging to the United States which were not in use if I could have them. He said "yes," but that it would be impossible to find any. I left him and told Fitz Henry Warren about the arms General Harney had spoken of, and he, being far more astute than I, made the bargain with Secretary Cumeron a little more definite and certain. We found the arms, and having obtained an order from the Secretary of War, they were shipped to Iowa. There were six thousand stand, a portion of which were sent direct to my own regiment, the Fourth Iowa, of which I had been made Colonel. In going to their destination these arms passed through Keokuk and Burlington. About the time they reached Iow a there was a great alarm on the border, in fact a great scare, and reports that the Missourians were marching in force upon Keokuk. General Cyrus Bussey, who was either in command or was present here at that time, has since informed me that he was the person who seized these arms and distributed them to the organizations that 
were forming in this vicinity to meet the Missourians. The Fourth Iowa never saw a single one of these guns. After all my labors, when my regiment reached St. Louis it was armed with old Prussian muskets, and the first time the boys fired them thirteen of them burst; they were more deadly at the butt than at the muzzle.

All this time I was in frequent correspondence with Crocker. He was close to headquarters at Des Moines, and never ceased to sing my praises. While I was in Washington a Brigadier General was allotted to the State of Iowa, and Fitz Henry Warren wanted me to take the appointment, but I felt that it was too great a responsibility for one of my experience, and declined it. Then Secretary Cameron, who had formed a better opinion of me after my having obtained the arms, asked Governor Kirkwood to appoint me Colonel of an Iowa regiment. Kirkwood immediately responded by making me Colonel of the Fourth Iowa Infantry, with instructions to recruit and rendezvous it at Council Bluffs.

Crocker heard of the offer of the star, and my timidness in connection with it, and wrote me a letter indicating that he was about to lose faith in me. He had built me up so to others that he had come to believe himself that I could acceptably fill any position, and that in declining this appointment I had lost a great opportunity. That generalship was given to General S. R. Curtis and the next to General Thomas J. MeKean. Every time an appointment was announced Crocker came at me declaring what a fool I had been, and what opportunities I had lost.

The old Council Bluffs Guards joined the Fourth Iowa, every man in the company enlisting. Lieutenant W. H. Kinsman became its Captain, but was soon selected as Colonel of the Twenty-third Iowa, and fell leading his regiment at the charge of the Black Bayou. Lieutenant George E. Ford succeeded him as Captain, and fought through the war. When the company returned home it kept up its organization, and honored me by changing its name to "The Dodge 
Light Guard." The sons of the old veterans joined the company, and when the Spanish war came they followed the example of their fathers and enlisted unanimously as Company $\mathrm{L}$ of the Fifty-first Iowa Infantry. They, too, were a great credit and honor to the State. They returned home and are now a flourishing company of the new Fifty-first-a part of the National Guard of the State. You who understand all the ups and downs and struggles of that frontier company, will appreciate how I love and honor them, and how proud I am of their record. It is an object lesson to the young men of our State, and if they want to learn to respect power and government, be taught obedience and discipline, and obtain physical development that will last them through life, let them join a company of the National Guard. The State now furnishes every inducement, the government arms, equips and uniforms them, and the legislature has made ample provision and is generous in its appropriations to sustain them.

Soon after Crocker entered the Second Iowa he was promoted to the command of the Thirteenth Iowa Infantry, and it was not long until he was in command of this Crocker Brigade. He won his star and received his appointment as a Brigadier General in 1862, for his masterly handling of his brigade at the battle of Pittsburg Landing. I do not say this from my own observation alone, but also from the testimony of those with whom I was closely associated, who never failed to speak of Crocker when the State of Iowa was mentioned. Sherman and Grant were his friends, and Grant did everything in his power to prolong his life. Many and many a time has he spoken to me of his great promise. After every battle I fought, every promotion I obtained, every new command I was raised to, Crocker was the first to write to me and send his congratulations, and it seemed to break his heart to think how I had at first failed to grasp my opportunities.

THE FOURTH IOWA INFANTRY IN THE BATTLE OF PEA RIDGE.

The record of the Fourth Iowa is known to all of you. When I organized it I drilled and disciplined it until the 
boys were wishing I was "in Halifax." I endeavored to put them through the same motions they would go through in battle, and over similar ground, and drove them through brush and over hills until the officers said I would bankrupt the boys on account of the new clothing they had to buy, but in their first and last great battle under me, Pea Ridge, where they stood when all others had gone, where, when night came, and they lined up with not a man missing except those who were dead or wounded, and when they were coming off the field of battle without a round of ammunition, they received that great compliment from General Curtis, and under his order charged the enemy with their bayonets across the open field, then it was that they realized what drill and discipline had done for them, and enabled them to do for their country. They saw regiments uselessly exposed and melt away. They then unanimously forgave me for all the hard knocks to which they had been subjected. Sheridan, who was then a quartermaster, speaks in his memoirs of their work for him in this eampaign, and said they would always have a warm place in his heart.

GENERAL SAMUEL R. CURTIS ENTITLED TO CREDIT FOR SUCCESS OF PEA RIDGE.

At Pea Ridge, which was one of the longest, hottest and most destructive battles, for the number engaged, of any fought in the West, the Fourth Iowa won my first star, and the regiment then fell to the command of one of Iowa's best and bravest officers, General James A. Williamson. In the first reports of this battle that reached the people, the newspapers gave the credit of winning the great victory to General Franz Sigel, and his troops. While that portion of his command that was engaged in the first two days did splendid work, especially a portion of General P. J. Osterhaus' division, still the greater part of General Sigel's command did not take part in the battle until the last day, when one-half of Van Dorn's army had been already defeated by General Jeff. C. Davis, and had fled south, and on the last day we had 
only General Sterling Price to meet, who retreated as soon as we attacked him. General Sigel's losses, although he commanded nearly one-half of Curtis' army, were small compared with those of E. A. Carr's and Jeff. C. Davis' divisions. Probably no one had a better opportunity than I to judge this battle. My command opened the fighting, and, I think, was the last to fire a gun. General Curtis, the commander of that army, was entitled to the full credit of that great victory. That battle virtually cleared up the southwest, and allowed all our forces to concentrate on or east of the Mississippi. General Curtis had under him as division commanders several experienced, educated soldiers, who met and defeated on their own ground, three hundred miles away from any base, a force twice as large as his own. General Curtis was attacked in rear and on the flank with great force, the fighting lasting three days, and he defeated, yes, virtually destroyed, General Earl Van Dorn's army, and here, in his home, I take pleasure in giving to him the full credit that he is justly entitled to.

General Crocker's first anxiety when he heard of the battle was for me. The first reports indicated that I had been given a permanent leave by the Confederates, but when he found that I was good for another campaign and had received a promotion, he opened up on the press that had endeavored to take the credit for the victory from his first Colonel, General Curtis. As soon as I was fit for duty I reported to General Halleck, and took a division with headquarters at Columbus. Crocker was then at Bolivar, Tennessee, and wrote me under date of August, 1862, that he was still in command of the Iowa Brigade, and that the creation of new regiments would probably keep him in command of a brigade.

COLONEL M. M. CROCKER APPOINTED BRIGADIER GENERAL.

Immediately after the battle of Corinth, October 3, 1862, I was assigned to the command of the Second Division, Army of the Tennessee. This was the division that Grant. 
had organized at Cairo. Crocker's old regiment, the Second, and Colonel Elliot W. Rice's Seventh Iowa, were in it. Crocker, as I have stated, had been appointed a Brigadier General, but the Senate had failed to confirm him in that position. Here was my opportunity to return in part some of the favors he had shown me, and I immediately took the matter up with our delegation in Congress, urging his reappointment and confirmation. Governor Kirkwood, and Hon. John A. Kasson, my own representative, responded promptly, but the matter dragged along, and for a time nothing was accomplished. In the meantime, Crocker with his brigade had gone to General Grant down the Mississippi, and on February 13, 1863, he wrote me as follows:

Lake Providence, La., Feb. 13, 1863.

After spending ten days encamped opposite Vicksburg, we were ordered to this place, which, by the way, is a most delightful situation, for what purpose I am unable to say. I hear of you frequently. I saw Gen. Grant this morning, and asked him if you were not to be ordered to the front. He said that you were a good man for any place, but that you could not be spared from Corinth. This division, you perhaps know, is in McPherson's army corps, the 17th, I believe, composed of McArthur's, Logan's and Quinby's. As far as I can judge, it is in much better condition than any other portion of the army down here, indeed, I do not think that erowd of poorly cared for, poorly drilled, discouraged and sick fellows that I saw in the mud opposite Vicksburg can properly be called an army. No enthusiasm, no discipline, no pride, not anything that leads to success in fighting. I was greatly disappointed, and, I confess greatly discouraged; the men are as good as any, but there is something wrong and $I$ fear it is in the officers. I saw Col. Williamson; he was not looking well-had not fully recovered from his wounds received at the storming of the works at Vicksburg. I did not see your old regiment. I am satisfied that the authorities at Washington made a great mistake in not brigading the troops from each state and putting them in divisions together to be commanded by their own officers, for after all, public opinion at home is the tribunal most feared, and if we command men from our own state we are more interested to take care of them.

I received a letter from Tuttle today; his health he says is bad. I am sorry to hear it, for I hoped to see him down here. Ransom is in our division, commands the $2 \mathrm{~d}$ brigade. He is a glorious good fellow. Do find time to write me a few lines, if not more.

General Crocker often refers in his letters to General T. E. G. Ransom, of whom he had often heard me speak. 
Ransom and myself were cadets together at Norwich University, and, like Crocker, he had a great future in the army, for he was a splendid soldier. You all remember that he died on a litter while in command of my corps, on the chase after Hood in the fall of 1864 . Like Crocker, he was one of my closest and dearest friends. He remained on duty when he should have been in the hospital, simply because he was fearful something might happen to the corps during my absence. After his death General Sherman paid him the highest possible tribute that could be spoken of a soldier.

On the first of February, 1863, Congressman Kasson wired me as follows: "I have this morning ascertained from Stanton in person that Crocker and Mathies are nominated to be Brigadier Generals." On February 27, 1863, I wired from Corinth to Kasson: "See that Crocker goes through; we must not lose him. Show this to the delegation. There is not an officer but backs him."

I cannot refrain from quoting here a dispatch from my old Adjutant, who succeeded me as Colonel of the Fourth Iowa, General J. A. Williamson. The dispatch is dated Vicksburg, January 28, 1863, and is as follows: "Crocker is here. Speaks highly of you and also says Governor Kirkwood has been urging my appointment as a Brigadier General. This is news to me as I have no aspirations in that way." You see our Iowa officers were doing their duty and earning their promotions from their records in the field. Crocker's nomination went through all right, and on March 19,1863 , he wrote me the following letter:

LETTER OF GENERAL M. M. CROCKER.

Lake Providence, LA., March 19, 1863.

I have delayed writing for several days until I should hear from Washington, as my future course depended somewhat on the result there. We have just heard of my confirmation, and I am going in a day or two to Vicksburg to see Gen. Grant. I feel so grateful to you for the interest that you have manifested in my promotion, and the service that you have rendered me, that I could swim the bayous from here to Vicksburg to do you a favor. When I return from there I will write you fully. 
As far as I ean see, military matters here are at a standstill. Until more troops can be brought down, all the schemes about ehutes, eut-off and canals seem to be humbugs, gotten up for the purpose of killing time and distracting attention from the real game; but something may happen soon. I wish you were here.

The campaign in the rear of Vicksburg was a severe one, and after it was over Crocker had to take a leave of absence. The fatal disease that had hold of him was developing, and we all knew it. General Grant was aware of it, and tried to save him, for in this campaign he developed the soldierly qualities that we all knew he possessed. After arriving at Des Moines he wrote to me as follows:

Des Mornes, July 2, 1863.

I have been absent from Vicksburg, you know, for some time. When the movement from Milliken's Bend commenced General Quinby was absent sick, and I was ordered forward to take temporary command of his division. I overtook the division at Port Gibson, just after the fight, and bad command of it at the battles of Raymond, Jackson, and Champion Hills, and up to Vicksourg, when Quinby having returned, I was relieved and made Chief of Staff for the Seventeenth Army Corps; a nominal position for the purpose of enabling me to stay around until after the fall of Vicksburg - we then thought of taking it by storm. I waited eight days and until the idea of storming was abandoned, and then obtained from General MePherson an order to report at St. Louis for medical treatment; came to St. Louis and had an operation performed on my throat and got leave to come home. My health is much improved, and I will start back on the 5th.

During the time I commanded Quinby's division it acquitted itself with great eredit, and I made some reputation out of it. I do not know what command I will have when I get back but the best one at their disposal, I think,

It was a good thing to get rid of MeClernand, and now that he has gone, I do not think there ean be much difficulty. I like Ord, and think he will do.

I came home in time to be present at the Republican convention. I found them hell-bent on nominating some military hero. Warren and Stone were both on hand urging their claims. I could have been nominated, but declined peremptorily. I told them that if they must nominate a military man to select one who had seen the enemy, and who had a good record, and suggested your name, but when asked if you would accept, I was compelled to say I did not believe you would, with your views and prospects, consent to sever your connection with the army. Had I felt at liberty to give any assurance in your name you would have been easily 
nominated. They did not want Stone, but preferred Stone to Warren. The Copperheads talk about nominating Tuttle, but Tuttle won't accept.

After a short stay at Des Moines, Crocker returned to Vicksburg and wrote me the following letter, which I read to show you his high sense of honor, his unselfishness and his attachment to a friend:

VIOKSBURG, July 21, 1863.

I arrived here yesterday and found the eity warm, dusty and generally as disagreeable as possible. I have been assigned to the command of Lauman's division (the Fourth), at present attached to the Thirteenth Army Corps, General Ord's. I have not reported for duty yet, but am waiting for the corps to return from Jackson; will probably start out in that direction tomorrow. Our old friend Lauman has been relieved. His force came upon the enemy strongly posted, with a battery, his skirmishers being advanced about thirty yards, so that he was cut up before he knew what was the matter. He thinks he exereised abundance of caution, and that great injustice has been done him. General Tuttle is out in the direction of Jackson with General Sherman. I have not seen him and cannot hear much of him. I wonder what he will think of the action of the Copperhead convention?

Ransom is at Natchez capturing beef, but will return in about ten days. In the siege he greatly distinguished himself and deservedly stands very high.

General Grant in connection with the order assigning me to duty with General Ord, ordered Rawlins to give me an order to him, which I will take the liberty to send you a copy of:

General: I am directed by the Major General Commanding to say that Brigadier General M. M. Crocker has been ordered to report to you with the view to his assignment to the command of Lauman's division. He is an officer brave, competent and experienced, in whom you may place the fullest confidence, and grant the greatest discretion without fear of the one being misplaced or the other imprudently given.

Signed,

John A. Rawhins, A. A. G.

General Grant takes every oceasion to speak in the highest terms of you and myself as the two Iowa men in whom he takes stock; he may be mistaken, but it is none the less a compliment to us.

Quite a number of Colonels have been recommended for promotion, but no Brigadiers have as yet been recommended. I do not know that any will be. I know that you ought to be promoted. After you, my claims are just as good as anybody's. I would not, if I could obtain it, accept promotion at your expense. Tuttle deserves promotion, if he had not allowed himself to be hurt by his political aspirations, that may stand in his way. I will see him as soon as I have an opportunity, and if he thinks be can make the riffle I must help him. One thing is certain, I cannot enter into com- 
petition with a man who has been as good a friend to me as Tuttle. Let me hear from you.

GENERAL JOHN A. RAWLINS' VISIT TO WASHINGTON.

After the fall of Vicksburg General Grant sent General Rawlins to Washington for the purpose of giving the President a full account of his campaign, and also sent by him his recommendations for promotions. On that list General Grant had done me the great honor toplace me at the head of the list for promotion to the rank of Major General. Many of you can remember the very favorable impression General Rawlins made. He appeared before the President and his Cabinet and gave that remarkable description of Grant and his Vicksburg campaign, and what he said on that occasion fully developed to the world the great qualities of that modest man. The only recommendation Grant made at that time for promotion that they acted upon was to make Rawlins a Brigadier General. Not one of the other recommendations, even after many subsequent requests from Generals Grant and Sherman, was acted upon until the year following. Grant and Rawlins supposed that such a great victory would bring several promotions, but the pressure east was so strong that Rawlins afterwards said that Vicksburg was almost forgotten.

I had recommended that Colonel Elliot W. Rice, of the Seventh Iowa, be made a Brigadier General. He was an admirable soldier. To make sure that my recommendation reached General Grant's personal attention, I sent it in a letter to General Crocker, who knew Rice, and asked him to present it and add his recommendation. In August, 1863. I received this response from Crocker:

I took your recommendation of Colonel Rice to General Grant, and he endorsed a strong approval on it. He told me that he had recommended you for promotion in the strongest terms, and that you would be made Major General. I hope you will be, and since talking with him have no doubt you will be. Let me hear from you.

In August, 1863, General Crocker was transferred from the Thirteenth to the Seventeenth Army Corps with his di- 
vision and General T. E. G. Ransom's brigade, and was assigned to the command of the district from Grand Gulf to the Louisiana state line. You are all aware that he stayed with his command much too long for the good of his own health, for when General Grant left Vicksburg there was no one to watch over him or send him away. I wrote General Grant what I had heard about Crocker's condition, and suggested that he be given a command on the plains, or in a climate better adapted to his condition. I also wrote to Crocker, and received the following letter from him while I was in the Atlanta campaign:

Des Mornes, 24th June, 1864.

Yours of June 9th has just come to hand. I am rejoiced to hear from you. I have all the time heard of you. I desire before saying anything more to congratulate you upon your promotion. Your friends here are greatly pleased thereat, none of them more pleased than myself.

I yielded to the necessity that compelled me to leave the field with great reluctance, and hoping against all probability, I stayed longer than I ought, so that I came very near dying, but I am better and improving rapidly, I think.

I do not know what disposition they are going to make of my resignation at Washington. I received a dispatch from Governor Stone and a letter from Kasson to the effect that the Secretary of War would arrange for me a separate command on the Pacifie, thereby giving me a chance to try the effect of a change of climate on my bronchitis. In answer to these I sent to the Secretary a withdrawal of the resignation upon the condition that I was assigned to such command, but I am not particular about it, and since I can't serve with my old comrades I don't much care to stay in the army.

If you see Clarke say to him that I have been expecting a letter from him. And do please write, to me yourself whenever you can find time. I suspect you are now pretty busy. Whenever I learn what disposition is to be made of my case I will write you. There is no news. Kasson will be renominated without a dissenting voice. Hub Hoxie sends his regards; he lets on to be very busy and I suppose that he is. He says he has a kind of general supervision of affairs, eivil and military, in the State, and has divers times threatened me with arrest, and since $I$ find his office a very convenient place to sponge stationery, envelopes, \&c., I have not seen proper to dispute his authority. Let me hear from you soon.

ASSIGNMENT OF GENERAL CROCKER TO DUTY IN DEPARTMENT OF NEW MEXICO.

Upon request of General Grant, General Crocker was sent to New Mexico to report to General James H. Carleton, 
in hopes that the dry climate would restore him to health. There was nothing for him to do there but get well, but he was restless, and chafed under the fact that he could not be in active service. He appreciated that his disease was making rapid strides, and therefore decided to go home to die.

In December, 1864, after recovering from the Confederate leave of absence given me in front of Atlanta, I was assigned to the command of the Department and Army of the Missouri, and soon afterward the Department of Kansas, then commanded by General Curtis, was merged into mine, in order that I could make the Indian campaigns that followed in the winter of 1864, 1865 and 1866. Crocker kept in correspondence with me, but I was on the plains most of the time, and away from communication, and it was a long time before his letters reached me. On his return from New Mexico he went to Washington, and I received from him this letter:

Chicago, Ilis., May 17, 1865.

I arrived at this city last night a good deal tired out, but am rested, and start home by Dix's Air Line at 7 o'clock this p. $\mathrm{m}$.

I have heard today from a New Mexican gentleman that Major General McCook has been ordered to New Mexico to supersede General Carleton, and that MeCook has passed through St. Louis en route. Let me know if you heard anything about this; if you saw MeCook and know from him his destination.

Secretary Stanton told me to write General Carleton and say to him that he duly approved his official conduct in managing his department, and that the General might rely upon the support of the War Vepartment. He did not mention MeCook.

Now, if at the time the Secretary told me I might write these things a General was on the way to Santa Fe with the Secretary's own order to relieve Carleton, it would look like very unnecessary trifling; indeed I can't believe it. But, if it turns out to be true, then I will write a private letter to Secretary Stanton giving him my views of his conduct. This, if he were fifty Secretaries of War and I much less able than I am to "turn a tide in a dead eddy." Let me hear from you.

General Alex. McD. McCook, whom Crocker mentions, had not been ordered to New Mexico, but had been sent out to my department with a commission to make treaties with 
the Indians. I wrote Crocker to this effect, and in answer received this letter:

Des Mornes, 24th May, 1865.

I arrived home all safe and am improving rapidly, I think. At any rate, I am able to circulate to some extent. I found $\mathrm{my}$ wife and all my babies well, and everything at home satisfactory. Have not seen many of the people; they seem to be jogging along very much after the same old sort.

I am very much relieved to learn that MeCook was not ordered to New Mexico. Of course if he had gone to relieve Carleton, Carleton would have said at once that the statement contained in my letter of my conversation with the Secretary of War was a lie, and it wonld look deeidedly like it. I see that Sheridan has gone to Texas. This, I suppose, will prevent an expedition from your department. However, I don't think it will make much difference. Kirby Smith will probably disband or surrender, and if you made the expedition all there would be of it would be a hard summer's work and very little glory, for the public are so hell-bent on considering the war closed that no expedition that can now be made would attract much attention,

I do not know what I will do, only if I live I will try to draw my pay regularly during my ninety days' leave, and maybe by the time my leave is out I can make up my mind.

Give my kind regards to Hub, and let me hear from you.

The expedition Crocker refers to in the foregoing letter was one Grant had ordered me to make through Southeast Missouri, Arkansas and Texas, to clear up the forces there which had refused to surrender. They included Generals Jeff. Thompson, Kirby Smith, Taylor and others. My force had only reached White River when Thompson, with about six thousand men, surrendered, and the other forces surrendered at the same time to General E. R. Canby, which, as Crocker suspected, closed up my campaign in that direction.

\section{DEATH OF GENERAL CROCKER.}

Soon after this I started on a campaign against the Indians that took me as far north as the Yellowstone River, and I heard nothing more from General Crocker until I received a telegram out on the plains from my aid, Major George C. Tichenor, notifying me of General Crocker's death, which occurred in Washington on August 28th. I was too far away to hear or take part in the tribute paid him by his State 
and country, who knew the value and appreciated accordingly his services. His commanding officers placed such a high value upon his ability that they used every means to prolong his life. He would have preferred to fall at the head of his column in battle, but, like the good soldier he was, he was willing to take whatever was in store for him. Nothing I can say to this brigade tells so forcibly and clearly of the man as the personal narrative I have so imperfectly given you. Crocker stamped himself a natural born soldier the moment he put on his uniform. Every commanding officer mentioned his services and recommended him for promotion. They had all great faith in his ability and judgment. His bravery was unquestioned, and had he retained his health he would have risen to the highest rank and command in the army.

The great State of Iowa has perpetuated his name and fame in the monument they have raised to him in our capital, but no work of painter or sculptor can picture him to the world as his commanding appearance and soldierly acts are impressed upon the minds of you, who served so faithfully with him.

You are assembled at the home of another of your commanders, who was also a close personal friend of mine. We who knew him best honor him most, and as time goes by he is given the credit that his acts and services entitle him to receive. I can only pay my tribute to him. Everyone in the Crocker Brigade and Army of the Tennessee knew of our old friendship.

There is one circumstance connected with your brigade when General W. W. Belknap was with you and the Sixteenth Corps that may interest you. The night after the battle of Atlanta, on the $22 \mathrm{~d}$ of July, when you were lying on that bald hill where the battle had raged so fiercely, General Logan, General Blair and myself met under a tree near the Augusta Railway, just behind the intrenchments of the Fifteenth Corps that the Confederates had broken through and 
captured Captain J. C. DeGress' Battery, which was retaken by Colonel Aug. C. Mercer's Brigade of the Sixteenth Corps, and General C. R. Wood's Division of the Fifteenth. General Blair told General Logan that his force on Leggett Hill was nearly worn out fighting first on one side of the intrenchments and then on the other, and asked him to send a force to relieve them. On that night nearly every man in the Army of the Tennessee was in a similar situation. Mercer's Brigade of the Sixteenth Army Corps was bivouacked right near where we were standing, and I told Blair I would send that brigade in to relieve them. They reached you some time before midnight, and gave you a chance to have a deserved rest. Colonel Mercer's Brigade had that day fought on three parts of the battlefield. His own regiment, the Ninth Illinois Infantry, had been mustered out of service several days before the battle, and were awaiting transportation home. There was no reason why they should take part in the battle, but they went in with the rest of the brigade, and, as you know, lost heavily, and were a part of the command that went to your relief. Of such material was made that great Army of the Tennessee.

My comrades, I thank you for the invitation you have given me to be with you, and doubly so that it has presented the opportunity I have long wished for to pay my tribute to your great commander, General M. M. Crocker, and also to testify to the bravery of your other distinguished commander, General William W. Belknap, and testify to the respect, honor and love I bear him. 


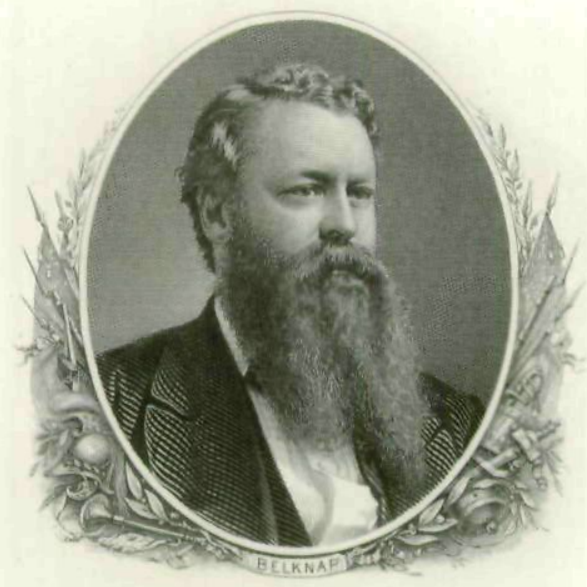

Burean. Engraving \& 17riutiug. 
Copyright of Annals of Iowa is the property of State of Iowa, by \& through the State Historical Society of Iowa and its content may not be copied or emailed to multiple sites or posted to a listserv without the copyright holder's express written permission. However, users may print, download, or email articles for individual use. 